Penelitian

\title{
Induksi dan Purifikasi Antibodi Anti-Coxiella burnetii untuk Deteksi Post Mortem Q Fever pada Ruminansia
}

\author{
(Induction and Purification of Anti-Coxiella burnetii Antibody for Post Mortem \\ Q Fever Diagnosis in Ruminants) \\ Nina Herlina ${ }^{1,2^{*}}$, Agus Setiyono ${ }^{3}$, Vetnizah Juniantito ${ }^{3}$, Syahruddin Said' $^{1}$ \\ ${ }^{1}$ Laboratorium Reproduksi, Pemuliaan dan Kultur Sel Hewan, Pusat Penelitian Bioteknologi, Lembaga Ilmu \\ Pengetahuan Indonesia, Cibinong, Bogor \\ ${ }^{2}$ Program Studi Ilmu Biomedis Hewan, Sekolah Pascasarjana Institut Pertanian Bogor, Bogor \\ ${ }^{3}$ Bagian Patologi, Departemen Klinik, Reproduksi, dan Patologi, Fakultas Kedokteran Hewan, \\ Institut Pertanian Bogor \\ *Penulis untuk korespondensi: nina.herlina.0212@gmail.com \\ Diterima 3 Februari 2018, Disetujui 16 Juli 2018
}

\begin{abstract}
ABSTRAK
Q fever merupakan penyakit zoonosis yang disebabkan oleh bakteri gram negatif Coxiella burnetii dan terdistribusi luas di seluruh dunia. Gejala klinis pada hewan ternak bersifat tidak konsisten dan tidak spesifik. Metode imunohistokimia telah digunakan untuk mendiagnosis kasus Q fever pada hewan ternak. Antibodi yang digunakan untuk metode imunohistokimia masih tergolong mahal dan harus diimpor dari negara lain sehingga produksi antibodi menjadi peluang. Penelitian ini bertujuan untuk memproduksi antibodi poliklonal anti-C.burnetii dan mengkarakterisasi antibodi tersebut untuk mendeteksi antigen pada organ limpa, paru-paru, dan hati sapi dari Rumah Potong Hewan (RPH) di Medan yang sebelumnya telah dikonfirmasi positif C.burnetii. C. burnetii strain Nine Mile (NM) dan Complete Freund's Adjuvant (CFA) digunakan untuk menginduksi antibodi pada dua ekor kelinci New Zealand White (NZW) jantan berumur 10-16 minggu. Boosting dilakukan menggunakan immunogen yang sama dengan Incomplete Freund's Adjuvant (IFA) pada hari ke-14 pascainduksi. Pemanenan serum dilakukan pada hari ke- 24 pascainduksi. Purifikasi serum dilakukan menggunakan dua tahapan, yaitu presipitasi dengan ammonium sulfat saturasi $35 \%$ dan filtrasi gel dengan matriks Sephadex G-75. Konsentrasi akhir antibodi yang diperoleh adalah sebesar $11,3 \mu \mathrm{g} \mu \mathrm{L}^{-1}$. Sodium Dodecyl Sulfate Poly Acrylamide Gel Electrophoresis (SDS PAGE) dan Western Blot digunakan untuk mengkarakterisasi antibodi yang diproduksi. Selanjutnya dilakukan pewarnaan imunohistokimia menggunakan antibodi tersebut dan sebanyak $90 \%$ limpa, $100 \%$ paru, dan $100 \%$ hati bersifat imunoreaktif yang ditandai dengan warna kecokelatan pada sitoplasma makrofag. Hasil ini menunjukkan bahwa antibodi yang telah dipurifikasi tersebut mampu mendeteksi antigen C. burnetii pada ruminansia.
\end{abstract}

Kata kunci: Q fever, sapi, Coxiella burnetii, antibodi poliklonal, imunohistokimia

\begin{abstract}
Q fever is a widespread zoonosis due to the infection of a gram negative bacterium Coxiella burnetii. The symptoms of disease described in domestic animals have so far been inconsistent and not specific. Immuno-histochemistry has been used to confirm Q fever cases in domestic animals. Antibody used for immuno-histochemistry was imported and quite expensive. Therefore, domestic antibody production will be a great opportunity. The aim of this research was to produce polyclonal anti-C. burnetii antibody and to characterize the antibody immunohistochemically in detecting antigen in various cattle organs such as the spleen, lung, and liver from slaughterhouse in Medan which was previously detected immunohistochemically positive against C.burnetii. C. burnetii of Nine Mile (NM) strain and Complete Freund's Adjuvant (CFA) were used to induce antibodies in two 10-16-week-old male New Zealand White (NZW) rabbits. Boosting was done with the same immunogen and Incomplete Freund's Adjuvant (IFA) at 14 days post induction. Terminal bleeding was done at 24 days post induction. Ammonium sulphate saturation (35\%) was used for serum precipitation. The next step was purification using Sephadex G-75 and the concentration of anti-C.burnetii antibody was obtained i.e., $11,3 \mu \mathrm{g} \mu \mathrm{L}^{-1}$. SDS PAGE and Western Blot were used to characterize the produced antibody. Immunohistochemical staining using the anti-C.burnetii antibody produced earlier showed $90 \%, 100 \%$, and $100 \%$ immunoreactivity in the spleen, lung, and liver, respectively. The result indicates that immunohistochemical detection using the produced purified antibodies is able to detect antigens of $C$. burnetii in ruminants.
\end{abstract}

Keywords: Q fever, Cattle, Coxiella burnetii, Polyclonal antibody, Immunohistochemistry 


\section{PENDAHULUAN}

Q fever (Query fever) merupakan penyakit yang disebabkan oleh bakteri gram negatif bersifat obligat intraseluler Coxiella burnetii (Angelakis dan Raoult 2010, Cremoux et al., 2011). Q fever bersifat zoonosis (Jones et al., 2011; Wielders et al., 2015). Bakteri penyebab penyakit ini dapat bertindak sebagai agen bioterorisme, seperti halnya Antraks ataupun Brucella (CDC 2008). Keputusan Menteri Pertanian No.4026/Kpts./OT.140/3/2013 menyatakan bahwa Q fever termasuk ke dalam daftar jenis penyakit hewan menular strategis (PHMS) yang perlu mendapat perhatian (KEMENTAN 2013).

Manifestasi klinis $Q$ fever pada hewan umumnya tidak menciri sehingga sulit didiagnosis secara klinis. Namun, yang dikhawatirkan adalah terjadinya subfertilitas, infertilitas, metritis, endometritis, retensi plasenta, stillbirth, dan keguguran pada trimester akhir kebuntingan (Arricau-Bouvery dan Rodolakis 2005; Brom dan Vellema 2009; Rodolakis 2014). Metode untuk identifikasi $C$. burnetii antara lain dengan isolasi dan identifikasi bakteri, molekuler maupun uji serologis, dan imunohistokimia (Angelakis dan Raoult 2010). Beberapa penelitian terbaru mengenai deteksi keberadaan patogen ini menggunakan Polymerase Chain Reaction (PCR), Enzyme Linked Immunosorbent Assay (ELISA), dan teknik imunohistokimia mendapatkan hasil positif pada sejumlah sampel ternak di Indonesia (Mahatmi et al., 2007; Setiyono dan Subangkit 2014; Nasution et al., 2014).

Teknik diagnosis yang baik dan akurat merupakan salah satu landasan untuk pencegahan dan pengendalian penyebaran penyakit ini di lapangan. Salah satu komponen penting untuk diagnostik penyakit adalah antibodi. Antibodi tergolong sebagai protein imunoglobulin yang dapat berikatan spesifik dengan antigen tertentu.

Salah satu faktor penentu keberhasilan sensitivitas dan spesifisitas produksi antibodi adalah imunogen yang digunakan. Strain NM merupakan isolat $C$. burnetii yang bersifat "highly conserved", artinya memiliki epitop atau penentu antigenik yang juga dimiliki oleh strain-strain lain C. burnetii. Selain itu, strain ini termasuk ke dalam genomotype yang sama dengan penyebab $Q$ fever akut maupun kronis pada hewan dan manusia (Leroy et al., 2011). Strain NM fase II yang bersifat avirulen banyak dikembangkan di laboratorium karena kemampuannya menginvasi dan menginfeksi berbagai tipe sel lestari. Selain itu, fase II juga lebih mudah ditumbuhkan pada sel kultur dibandingkan fase I yang virulen (Miller et al., 2004). Hal tersebut menyebabkan strain ini umum digunakan sebagai standar pada berbagai penelitian mengenai Q Fever.

Saat ini, sebagian besar antibodi yang digunakan untuk diagnostik berasal dari produsen asing dengan harga yang tergolong mahal. Oleh karena itu, produksi antibodi dengan spesifisitas dan sensitivitas yang cukup baik, namun dengan harga yang lebih terjangkau, merupakan suatu peluang yang baik dan prospektif. Penelitian ini bertujuan untuk memproduksi antibodi poliklonal anti-C. burnetii dan mengkarakterisasinya. Antibodi tersebut kemudian digunakan untuk mendeteksi antigen dengan metode imunohistokimia, seperti yang diilustrasikan oleh Santos et al. (2009). Teknik ini banyak digunakan untuk mendeteksi keberadaan antigen penyebab Q fever pada organ hewan, seperti plasenta kambing, domba, dan sapi (Bildfell et al., 2000; Hansen et al., 2011).

\section{BAHAN DAN METODE}

\section{Waktu dan Tempat}

Penelitian dilaksanakan pada bulan November 2015 sampai dengan Juli 2016 di Rumah Sakit Hewan Pendidikan (RSHP) Fakultas Kedokteran Hewan IPB, Bagian Patologi FKH IPB, dan Pusat Penelitian Bioteknologi LIPI.

\section{Hewan Percobaan}

Penelitian ini menggunakan kelinci jantan strain NZW berumur 10-16 minggu sebanyak dua ekor dengan bobot badan 2,5 kg (Balai Penelitian Peternakan Bogor, Indonesia).

Material Penginduksi Antibodi Anti-Coxiella burnetii Isolat C. burnetii strain NMII dari sel kultur Vero yang digunakan merupakan koleksi dari National Institute of Infectious Disease (NIID, Jepang).

\section{Sampel Organ Sapi Positif Q Fever}

Organ limpa, paru-paru, dan hati yang positif $C$. burnetii diperoleh dari Rumah Potong Hewan (RPH) Kota Medan, koleksi Sangkot Sayuti Nasution (Balai Veteriner Medan, Indonesia).

\section{Desain Penelitian}

Semua metode yang dilakukan dalam penelitian ini telah mendapatkan persetujuan atas perlakuan etik dari Komisi Pengawasan Kesejahteraan dan Penggunaan Hewan Percobaan, Rumah Sakit Hewan Pendidikan FKH-IPB, Nomor 16-2015 RSHP FKH-IPB. Penelitian ini terbagi menjadi tiga tahapan, 
yaitu tahap produksi antibodi anti-C.burnetii, tahap purifikasi antibodi anti-C.burnetii, dan tahap aplikasi antibodi anti-C. burnetii dengan pengamatan histopatologi.

\section{Produksi Antibodi anti-Coxiella burnetii}

Kelinci jantan NZW berumur 10-16 minggu sebanyak dua ekor diaklimatisasi dan diberi obatobatan praperlakuan antara lain antiparasit, antibiotik, dan anthelmintik. Kelinci percobaan kemudian disuntik dengan imunogen $C$. burnetii isolat standar NM (Bank Isolate, NIID, Jepang). Imunogen dengan konsentrasi $250 \mu \mathrm{\mu g}$ dalam Phosphate Buffer Saline (PBS) ditambahkan dengan CFA (Sigma, USA) dengan volume $0.5 \mathrm{~mL}$ untuk induksi. Boosting dilakukan pada hari ke-14 pascainduksi imunogen menggunakan imunogen NM dan IFA (Sigma, USA) dengan volume yang sama.

Pada hari ke-28 pascainduksi, dilakukan pengambilan darah secara intrakardial. Kelinci dianaestesi dengan campuran ketamin (dosis 35 mgkg-1BB) dan xylazine (dosis 5 mgkg-1BB). Darah yang sudah terkumpul diinkubasikan pada suhu ruang $\left( \pm 25^{\circ} \mathrm{C}\right)$ selama dua jam dan dilanjutkan pada suhu $4^{\circ} \mathrm{C}$ selama satu malam (overnight). Serum yang diperoleh dipisahkan secara manual dengan aspirasi dan disempurnakan dengan sentrifugasi pada 10.000 xg selama 15 menit. Serum yang diambil disentrifugasi kembali pada $10.000 \mathrm{xg}$ selama 10 menit. Selanjutnya, serum yang diperoleh disimpan pada suhu $-2^{\circ} \mathrm{C}$ untuk proses purifikasi. Pengukuran konsentrasi antibodi masing-masing perlakuan dilakukan dengan menggunakan nanofotometer (Implen, USA).

\section{Purifikasi Antibodi}

Pemurnian antibodi dilakukan dengan dua metode, yaitu presipitasi dengan amonium sulfat sesuai dengan metode yang digunakan oleh DuongLy dan Gabelli (2014) dan filtrasi gel (Striegel et al., 2009). Presipitasi menggunakan amonium sulfat saturasi 35\% dilakukan dengan mencampur serum dan larutan amonium sulfat dengan jumlah yang sama secara perlahan. Selanjutnya, campuran disentrifugasi pada kecepatan $3.000 \mathrm{xg}$ selama 20 menit pada suhu $4^{\circ} \mathrm{C}$. Filtrat atau pelet yang didapatkan dilarutkan dengan PBS pH 7,4 sehingga didapatkan $1 / 4$ volume awal antibodi. Selanjutnya dilakukan dialisis dengan memasukkan serum terpresipitasi dalam kantung dialisis (Spectra Por, USA) dan menempatkannya dalam $\mathrm{PBS}$ pH 7,4 selama
24 jam pada suhu $4^{\circ} \mathrm{C}$ dengan penggantian PBS sebanyak tiga kali.

Proses pemurnian antibodi selanjutnya dilakukan dengan metode filtrasi gel dengan kolom kromatografi terbuka dengan matriks Sephadex G75 (Sigma, USA). Hasil purifikasi tersebut dikaji menggunakan metode SDS-PAGE dan Western Blot. Konsentrasi antibodi sebelum dan sesudah purifikasi diukur dengan menggunakan nanofotometer (Implen, USA).

Analisis SDS-PAGE (Sodium Dodecyl Sulfate Poly Acrylamide Gel Electrophoresis) dilakukan dengan Pewarnaan Comassie Brilliant Blue (CBB). Sampel antibodi yang dihasilkan dianalisis dengan metode SDS-PAGE (Ausubel et al., 2003) menggunakan konsentrasi poliakrilamid $12 \%$ untuk separating gel dan 3\% untuk stacking gel (Sambrook dan Russel 2001). Sampel antibodi $(15 \mu \mathrm{L})$ ditambahkan dengan $5 \mu \mathrm{L}$ buffer sampel (mengandung Tris/SDS, bromophenol blue, DTT dan gliserol) kemudian dipanaskan pada suhu $95^{\circ} \mathrm{C}$ selama lima menit untuk mendenaturasi protein. Sebanyak $15 \mu \mathrm{L}$ sampel antibodi dan $5 \mu \mathrm{L}$ marka protein (Page Ruler Prestained Protein Ladder, Thermo Scientific, USA) digunakan. Pemisahan protein dilakukan dengan elektroforesis pada tegangan $90 \mathrm{~V}$ selama 120 menit. Gel hasil elektroforesis diwarnai dengan CBB selama 30 menit yang dilanjutkan dengan penambahan destaining solution selama 24 jam.

\section{Analisis kompatibilitas antibodi dengan antigen}

Western Blot dilakukan untuk melihat kompatibilitas antara antigen dan antibodi yang diproduksi (Ausubel et al., 2003) dengan sedikit modifikasi. Gel dengan sampel isolat NM hasil elektroforesis yang tidak diwarnai $C B B$ ditransfer ke dalam membran nitroselulosa $0.22 \mu$ (Biorad, USA) yang sebelumnya telah dibasahi buffer elektro- transfer. Sandwich yang terbentuk dimasukkan ke dalam tangki electroblotting, kemudian dilakukan proses transfer dengan tegangan konstan $30 \mathrm{~V}$ selama semalam pada suhu $4^{\circ} \mathrm{C}$.

Membran yang sudah ditransfer direndam dan digoyang dalam larutan blocking ( $5 \%$ susu skim dalam TBS 1x) selama 60 menit, kemudian dicuci dengan larutan pencuci (TBS+0,05\% Tween 20) sebanyak tiga kali (15 menit; 5 menit; 5 menit) dan diinkubasi pada suhu ruang dengan antibodi primer produksi yang diencerkan dalam 3\% susu skim dalam TBS-T 1:1000 selama satu jam. Kemudian membran dicuci tiga kali dengan TBS-T dan ditambahkan antibodi sekunder HRPO conjugated goat anti rabbit lgG (Promega, USA) 
dalam TBS-T 1:3000, dan membran diinkubasi lagi selama satu jam pada suhu ruang. Pencucian blot dilakukan tiga sampai lima kali selama 5 menit dengan TBS-T dan membran diinkubasi lagi selama satu jam pada temperatur kamar. Blot kemudian dikembangkan dengan larutan substrat Tetramethylbenzidine (Merck, USA) sampai terbentuk warna biru keunguan.

Pembuatan Preparat Histopatologi dan Pewarnaan Hematoksilin Eosin (HE)

Sampel organ limpa, paru-paru, dan hati dipotong dengan ketebalan kurang lebih $3 \mathrm{~mm}$ dengan menggunakan mikrotom kemudian dimasukkan ke dalam tissue cassette selanjutnya dimasukkan ke dalam automatic tissue processor (Sakura Tec, Belanda). Proses pembuatan preparat histopatologi dan pewarnaan rutin HE dilakukan sesuai dengan metode Day (2014).

\section{Pewarnaan Imunohistokimia}

Pewarnaan imunohistokimia dilakukan sesuai Ramos-Vara (2005) dengan sedikit modifikasi menggunakan kit imunohistokimia (EnvisionTM Dual Link Systems DAKO, USA). Blocking normal serum dilakukan dengan menggunakan susu skim 5\%. Inkubasi dengan antibodi primer (antibodi Rabbit anti C. burnetii) dilakukan pada pengenceran 1:500.

\section{Analisis Data}

Data dianalisis secara deskriptif melalui tabel hasil pengukuran konsentrasi protein dan tabel hasil pengujian imunohistokimia. Selanjutnya ditampilkan gambar deskripsi SDS PAGE, Western blot, lesio histo- patologi yang ditemukan pada pewarnaan HE serta distribusi antigen $C$. burnetii pada pewarnaan imunohistokimia.

\section{HASIL}

\section{Produksi Antibodi Anti-C.burnetii}

Data konsentrasi serum darah kelinci NZW pascainduksi dan pascaboosting antigen yang diukur menggunakan nanofotometer ditunjukkan pada Tabel 1. Hasil penelitian memperlihatkan adanya peningkatan konsentrasi antibodi pascaboosting pertama. Kondisi ini merupakan kondisi yang cukup optimal untuk pemanenan serum sehingga tidak dilakukan boosting ulangan.

\section{Purifikasi Antibodi Anti-C.burnetii}

Volume dan konsentrasi antibodi dalam berbagai tahapan pemurnian ditunjukkan pada Tabel 2. Volume darah awal dikonsentrat menggunakan amonium sulfat dan Sephadex G-75 menjadi 3\% dari volume awal serum yang diperoleh. Total serum sejumlah $38.9 \mathrm{~mL}$ dipurifikasi menggunakan metode presipitasi dan filtrasi gel. Hasil perhitungan menggunakan nanofotometer, diperoleh konsentrat protein senilai $4 \mu g \mathrm{~L}^{-1}$.

Proses dialisis meningkatkan konsentrasi menjadi $5 \mu \mathrm{g} \mathrm{L}^{-1}$. Tahapan selanjutnya adalah purifikasi dengan menggunakan kolom filtrasi gel terbuka dengan matriks Sephadex G-75. Metode ini menghasilkan konsentrasi akhir menjadi 11,3 $\mu g \mathrm{\mu L}^{-1}$.

Visualisasi antibodi sebelum dan sesudah purifikasi dengan SDS PAGE ditunjukkan pada Gambar 1.

Tabel 1 Hasil pengukuran konsentrasi serum darah kelinci NZW

\begin{tabular}{ccc}
\hline \multirow{2}{*}{ Tahapan } & \multicolumn{2}{c}{ Konsentrasi $\left(\mu \mathrm{g} \mu \mathrm{L}^{-1}\right)$} \\
\cline { 2 - 3 } & Kelinci 1 & Kelinci 2 \\
\hline Pascainduksi Antigen & 1,200 & 1,366 \\
Pascaboosting Antigen & 1,633 & 2,042 \\
\hline
\end{tabular}

Tabel 2 Hasil pengukuran konsentrasi antibodi anti-C.burnetii setelah purifikasi

\begin{tabular}{lll}
\hline \multicolumn{1}{c}{ Fraksi } & Volume & Konsentrasi Antibodi \\
\hline Total Darah & $113 \mathrm{~mL}$ & - \\
Total Serum & $38,9 \mathrm{~mL}$ & $2,1 \mu \mathrm{gL}^{-1}$ \\
Konsentrat Amonium Sulfat & $18,6 \mathrm{~mL}$ & $4 \mu \mathrm{gL}^{-1}$ \\
Konsentrat Dialisis & $15,3 \mathrm{~mL}$ & $5 \mu \mathrm{gL}^{-1}$ \\
Konsentrat Sephadex G-75 & $1,2 \mathrm{~mL}$ & $11,3 \mu \mathrm{gL} \mathrm{L}^{-1}$ \\
\hline
\end{tabular}




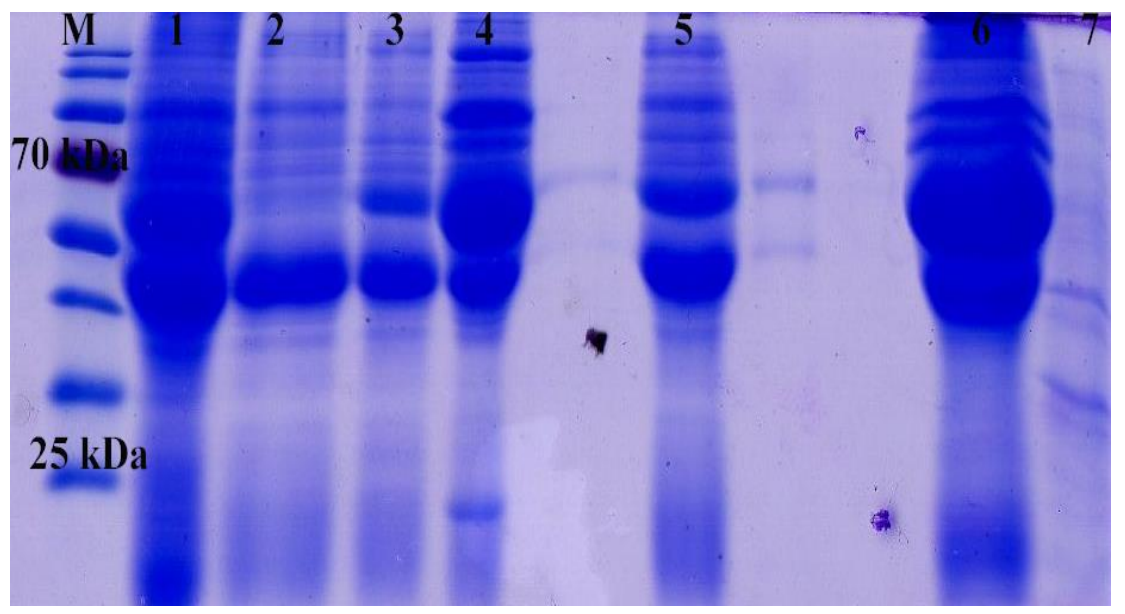

Gambar 1 Profil SDS-PAGE antibodi poliklonal anti-C.burnetii sebelum purifikasi dan pascafiltrasi Sephadex G75. Marka protein (M); Serum (lajur 1); Antibodi presipitasi amonium sulfat (lajur 2,3); Antibodi hasil dialisis (lajur 4); Fraksi hasil filtrasi dengan Sephadex G-75 (lajur 5); Antibodi komersil (lajur 6). Lajur 7 merupakan profil antigen C. burnetii NM II

Hasil SDS PAGE menunjukkan adanya beberapa pita, yaitu pada bobot molekul $170 \mathrm{kDa}, 100 \mathrm{kDa}, 65$ $\mathrm{kDa}, 50 \mathrm{kDa}$, dan $25 \mathrm{kDa}$. Pita teratas dengan bobot molekul $170 \mathrm{kDa}$ merupakan fragmen IgG yang tidak terdenaturasi, sedangkan pita dengan bobot molekul $25 \mathrm{kDa}$ merupakan antibodi light chain (rantai ringan) dan heavy chain (rantai berat) dengan bobot molekul $50 \mathrm{kDa}$.

Uji kompatibilitas antibodi dilakukan dengan menggunakan Western blot. Western imunoblot dinyatakan positif bila serum mengenal protein dari antigen yang diinfeksikan. Gambar 2 menunjukkan adanya warna biru keunguan pada bobot molekul 35,5 kDa, 51,4 kDa, dan 58,284 kDa.

\section{Aplikasi Antibodi anti-C.burnetii dengan Imunohistokimia}

Validasi antibodi anti-C.burnetii yang diperoleh dilakukan dengan menguji sampel organ dari RPH kota Medan. Pemeriksaan histopatologi dengan pewarnaan rutin HE organ limpa, paru-paru, dan hati ditunjukkan pada Gambar 3, sedangkan imunohistokimia ditunjukkan pada Gambar 4. Berdasarkan hasil pewarnaan $\mathrm{HE}$, limpa mengalami peradangan yang ditunjukkan dengan adanya infiltrasi sel radang berupa limfosit, makrofag, dan neutrofil (Gambar 3a). Pewarnaan dengan imunohistokimia terdeteksi adanya agen $C$. burnetii berwarna kecokelatan pada sitoplasma makrofag (Gambar 4a).

Paru-paru menunjukkan gejala pneumonia interstitialis, yang ditandai dengan penebalan dinding alveolar disertai infiltrasi sel radang (Gambar 3b). Pewarnaan imunohistokimia menunjukkan imunoreaktif dengan antibodi anti-C.burnetii (Gambar 4b).
Organ hati menunjukkan kejadian hepatitis yang ditandai dengan adanya kongesti yang disertai infiltrasi sel radang berupa makrofag dan limfosit (Gambar 3c). Hal tersebut merupakan lesio yang disebabkan oleh adanya agen infeksi C. burnetii (Gambar 4c).

Antibodi anti-C.burnetii yang diproduksi mampu mendeteksi adanya antigen $C$. burnetii pada sejumlah sampel yang diperiksa (Tabel 3 ).

\section{PEMBAHASAN}

Q Fever merupakan penyakit yang sering dihubungkan dengan ruminansia. Kontak dengan hewan ataupun produk hewan yang terinfeksi merupakan rute utama paparan patogen ini pada manusia. Gejala klinis yang tidak spesifik dan tidak konsisten pada ternak menjadikan penyakit ini sulit didiagnosis sehingga memerlukan teknik lain, seperti uji serologis maupun imunohistokimia.

Produksi antibodi dilakukan dengan menyuntikkan antigen untuk menginduksi sistem imun. Beberapa faktor yang dapat mempengaruhi proses pembentukan antibodi antara lain adalah imunogenesitas, kualitas, bentuk kelarutan, stimulan, spesies hewan, rute imunisasi, dan sensitivitas assay yang digunakan (Reverberi dan Reverberi 2007). Pemilihan antigen C. burnetii strain Nine Mile II dilakukan karena strain ini bersifat inaktif karena telah melalui pasase berulang sehingga tidak bersifat virulen, namun masih memiliki imunogenesitas. Penyuntikan antigen $C$. burnetii strain NM dilakukan sebanyak dua kali. Imunisasi pertama bertujuan memperkenalkan antigen 


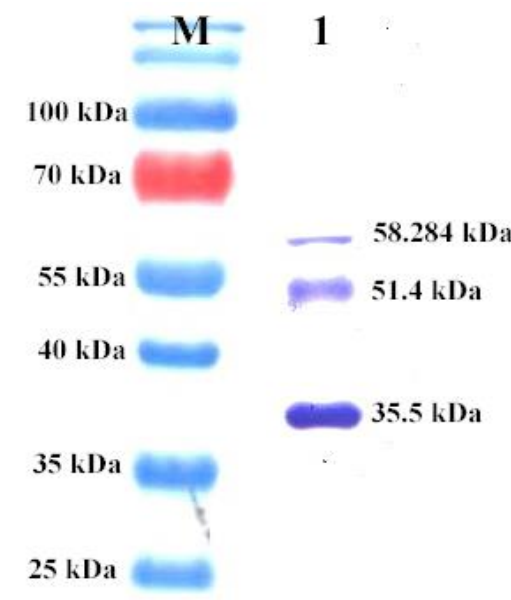

Gambar 2 Hasil imunoreaktif Western blot pada 35,5 kDa, 51,4 kDa, dan 58,284 kDa

Tabel 3 Hasil analisis imunohistokimia dengan antibodi anti-C.burnetii

\begin{tabular}{lcccc}
\hline \multirow{2}{*}{ Jenis organ } & \multirow{2}{*}{$\begin{array}{c}\text { Jumlah } \\
\text { sampel }\end{array}$} & \multicolumn{2}{c}{ Imunoreaktif } & \multirow{2}{*}{ Persentase Keberhasilan Deteksi Ab (\%) } \\
\cline { 2 - 4 } & 10 & 9 & 10 & 90 \\
Limpa & 10 & 5 & 5 & 100 \\
Paru-paru & 10 & 1 & 1 & 100 \\
Hati & 30 & 15 & 16 & 96,67 \\
\hline Total & Keterangan : * Hasil imunohistokimia positif dengan antibodi yang diproduksi & \\
& $* *$ Hasil imunohistokimia positif Nasution et al. (2014) dengan antibodi komersil
\end{tabular}

pada sel B dan imunisasi kedua sebagai booster atau ulangan dilakukan untuk meningkatkan produksi antibodi oleh sel B (Natih et al., 2010). Penggunaan CFA yang mengandung minyak pengemulsi dilengkapi Mycobacterium yang dilemahkan bertujuan untuk pembentukan radang granuloma agar pelepasan imunogen berlangsung perlahan dan bertahap sehingga merangsang fungsi makrofag (Leenaars dan Hendriksen, 2005). Selain itu CFA juga berfungsi untuk meningkatkan imunorespons dan memberikan isyarat kepada tubuh untuk membentuk antibodi apabila ada benda asing atau mikroorganisme yang masuk ke dalam tubuh. Pada proses boosting, adjuvan yang digunakan ialah IFA, yang merupakan adjuvan murni berupa minyak jagung. Adjuvan jenis ini digunakan untuk menjaga agar pelepasan imunogen berlangsung secara perlahan.

Umumnya, proses vaksinasi pada produksi antibodi dengan vaksin inaktif dilakukan sebanyak dua atau tiga kali. Vaksinasi pertama untuk memperkenalkan dan yang kedua sebagai booster agar imunitas yang dihasilkan cukup tinggi (Rantam 2005). Pada penelitian ini, terlihat bahwa kedua kelinci menunjukkan proses pembentukan antibodi terhadap C. burnetii pascainduksi dan boosting yang terlihat pada pengukuran konsentrasi protein menggunakan nanofotometer. Berdasarkan hal tersebut maka dilakukan pemanenan serum pada hari ke-24 sesudah induksi. Penentuan terminal bleeding ini juga mengacu pada Herbert et al., (1980) yang menyatakan pada hari ke-22 pascainokulasi $C$. burnetii yang telah dipurifikasi dapat menghasilkan titer antibodi Complement Fixation 1,024 dengan 13\% gamma globulin. Angka tersebut cukup tinggi dan akan bertahan sampai hari ke-41.

Purifikasi antibodi dilakukan dengan menggunakan dua tahapan purifikasi, yaitu presipitasi dan filtrasi. Pemilihan amonium sulfat untuk presipitasi serum dilakukan karena merupakan metode mudah dan ekonomis untuk pengkelat IgG. Menurut Oliver dan Jamur (2010), amonium sulfat saturasi 35\% mampu menghasilkan recovery $80-90 \%$ pada kelinci dan domba. Berdasarkan hal tersebut maka penggunaan saturasi $35 \%$ diharapkan mampu mempresipitasi IgG dengan jumlah optimum. Serum hasil presipitasi kemudian dilakukan dialisis dalam larutan PBS pH 7,4 selama 24 jam pada suhu $4^{\circ} \mathrm{C}$ yang bertujuan untuk menghilangkan garam-garam amonium sulfat pada tahap presipitasi. Tahapan selanjutnya ialah proses filtrasi dengan matriks Sephadex G-75. Sephadex G-75 merupakan matriks 


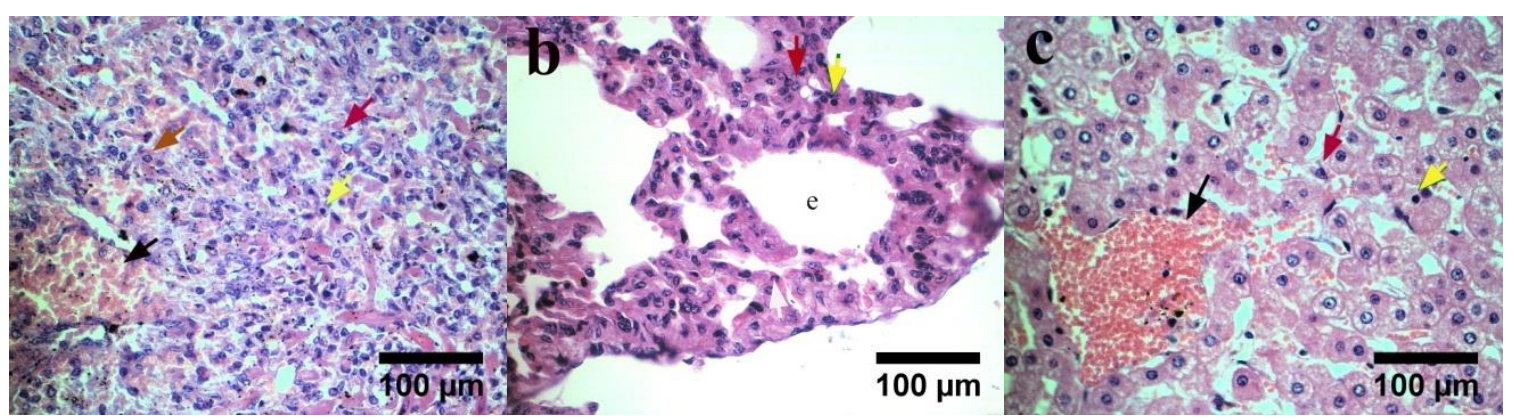

Gambar 3 Hasil pewarnaan HE pada limpa (a), paru-paru (b), dan hati (c). Tanda panah menunjukkan adanya kongesti. Infiltrasi sel radang limfosit (panah kuning), makrofag (panah merah), dan neutrofil (panah cokelat)

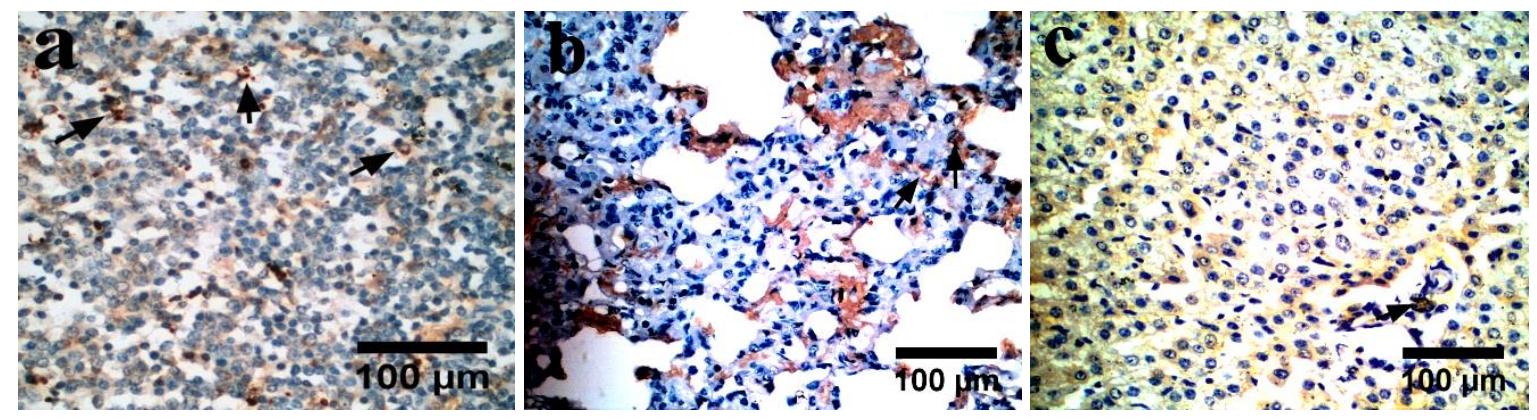

Gambar 4 Hasil pewarnaan imunohistokimia pada limpa (a), paru-paru (b), hati (c). Hasil imunoreaktif terhadap C. burnetii terlihat warna cokelat pada sitoplasma makrofag

berbasis dextran yang akan memisahkan molekulmolekul berda-sarkan bobot molekul protein. Umumnya metode kromatografi dipilih karena resolusi yang dihasilkan tinggi, namun perlu adanya kromatografi tambahan dan/atau tahapan lain yang diperlukan untuk mengatasi volume yang cukup besar dan adanya kontaminasi protein (Hjorth 1997). Penggunaan matriks ini juga berfungsi untuk pemekatan kon-sentrasi protein, mereduksi volume protein, dan memisahkan protein yang diinginkan dari konta-minan atau protein lain yang tidak dikehendaki (Rosenberg 2005).

Antibodi yang dihasilkan kemudian dikarakterisasi menggunakan analisis SDS PAGE dan Western blot. SDS PAGE dapat memberikan informasi mengenai bobot molekul protein dengan cara membandingkannya dengan marker atau penanda komersil yang terukur dalam satuan kilo Dalton (kDa). Hasil memperlihatkan adanya beberapa pita protein dengan bobot molekul $170 \mathrm{kDa}$ yang merupakan fragmen IgG yang tidak terdenaturasi, sedangkan pita dengan bobot molekul $25 \mathrm{kDa}$ merupakan antibodi light chain (rantai ringan) dan heavy chain (rantai berat) dengan bobot molekul 50 kDa (Gambar 1).
Analisis SDS PAGE imunogen yang digunakan untuk menginduksi antibodi anti-C.burnetii menunjukkan adanya dua pita protein dengan bobot molekul 35,5 kDa dan 51,4 kDa (Gambar 1). Selanjutnya dilakukan analisis Western blot untuk melihat kompatibilitas antara antigen dengan antibodi yang diperoleh. Proses ini dapat mengidentifikasi antigen spesifik sesuai dengan atibodi yang diaplikasikan pada membran yang dapat berupa membran nitroselulosa atau polyvinylidene difluoride (PVDF). Sampel imunogen yang telah terlebih dahulu dipisahkan melalui SDS PAGE kemudian ditransfer ke membran nitroselulose untuk dilakukan electrobloting. Setelah proses blocking dengan susu skim, membran diinkubasi dengan antibodi anti-C. burnetii selama satu jam dilanjutkan dengan inkubasi dengan antibodi sekunder yang telah terkonjugasi HRP.

Penambahan substrat TMB mengikat kromogen dan menghasilkan warna ungu pada pita $35,5 \mathrm{kDa}$, pita 51,4 kDa, dan 58,284 kDa (Gambar 2). Menurut Kowalczewska et al. (2011), outer membrane protein (OMP) dari fraksi C. burnetii strain NM II memiliki bobot molekul 35,5 kDa, pita 51,4 kDa merupakan hypothetical membrane protein NM II sedangkan 
$58,284 \mathrm{kDa}$ sebagai chaperonin (Grol) soluble protein NM II. Hal tersebut sesuai dengan profil imunogen berdasarkan SDS PAGE dan memastikan bahwa serum tersebut mengandung antibodi yang mampu mengikat imunogen yang diinfeksikan.

Aplikasi antibodi selanjutnya ialah dengan melakukan pewarnaan imunohistokimia pada sampel limpa, paru-paru, dan hati yang sama dengan terlebih dahulu melakukan pemeriksaan histopatologis dengan pewarnaan rutin HE. Pemeriksaan mikroskopis pada kejadian Q fever umumnya bersifat tidak spesifik (Parker et al., 2006). Berdasarkan hasil penelitian, terlihat adanya splenitis yang ditunjukkan adanya infiltrasi sel radang makrofag, limfosit, dan neutrofil pada pulpa merah (Gambar 3a). Lesio histopatologi lain ialah adanya edema, kongesti pulpa merah, dan deplesi pulpa putih. Kelainan tersebut dapat disebabkan oleh adanya infeksi C. burnetii ataupun hal lainnya. Menurut Nasution et al. (2014), lesio yang dapat ditemukan pada infeksi Q fever di antaranya populasi sel-sel radang makrofag dan neutrofil pada pulpa merah, kongesti, pigmen hemosiderin, serta deplesi folikel limfoid. Beberapa lesio yang dapat terjadi pada limpa antara lain deplesi pulpa putih, kongesti pulpa merah, adanya sel radang, neutrofil, dan limfosit (Setiyono, 2014).

Limpa merupakan organ limfoid sekunder terbesar yang tersusun oleh limfosit dan eritrosit dan secara fungsional membentuk pulpa merah dan pulpa putih (Kuper et al., 2002). Fungsi limpa sebagai filter material asing dan mikroorganisme serta membuang eritrosit yang sudah tua dan rusak, menyebabkan organ ini mudah terinfeksi dan dapat menunjukkan keberadaan antigen (Fry dan McGavin 2006). Deteksi keberadaan C. burnetii pada Gambar 4a menunjukkan adanya hasil imunoreaktif berwarna cokelat di sitoplasma makrofag. Hal tersebut sesuai dengan $C$. burnetii sebagai mikrob obligat intraseluler yang dapat ditemukan di dalam makrofag (Angelakis dan Raoult 2011).

Pemeriksaan mikroskopik paru-paru menunjukkan adanya pneumonia interstitialis yang ditandai dengan infiltrasi sel radang berupa limfosit, makrofag, dan neutrofil pada interstitial paru-paru (Gambar 3b). Infiltrasi sel radang makrofag, limfosit, dan neutrofil akan menyebabkan pelebaran septa interalveolar. Stein et al. (2005) menyatakan bahwa infeksi C. burnetii secara eksperimental menyebabkan inflamasi pada hari ke-7 dan 14 pascainfeksi. Kejadian inflamasi ini ditandai dengan infiltrasi sel mononuklear yang terdiri atas makrofag dan limfosit yang memenuhi dinding alveol dan membentuk pneumonia interstitialis. Keadaan tersebut banyak ditemui pada kasus kronis di mana mikroorganisme sulit untuk difagosit. C. burnetii merupakan agen infeksi yang sering berjalan kronis dan secara persisten mengeluarkan agen tersebut melalui feses dan urin (Angelakis dan Raoult 2010). Lesio lain yang ditemukan ialah adanya emfisema.

Emfisema paru-paru merupakan suatu perubahan anatomis parenkim yang ditandai dengan pembesaran alveolus dan duktus alveolaris, serta destruksi dinding alveolar. Emfisema dapat terjadi akibat adanya peningkatan jumlah makrofag alveolar dan neutrofil atau akibat meningkatnya dinding alveol yang mengalami nekrosa (Sharafkhaneh et al., 2008). Menurut Nasution et al. (2014) perubahan lain yang ditemukan di paru-paru adalah kongesti, perdarahan, edema, dan adanya atelektasis. Deteksi keberadaan antigen dengan antibodi anti-C.burnetii menunjukkan hasil imunoreaktif (Gambar 4b). Hal tersebut membuktikan lesio yang terjadi merupakan salah satu manifestasi dari $Q$ fever.

Respons imun pada kejadian Q fever dihubungkan dengan adanya reaksi peradangan yang dapat menimbulkan pembentukan granuloma yang umumnya dapat ditemui di paru-paru, hati, ataupun sumsum tulang (Fournier et al., 1998). Pada pemeriksaan sampel, tidak ditemukan adanya granuloma pada paru-paru maupun hati (Gambar 3). Namun infiltrasi sel radang seperti makrofag ataupun limfosit dan fokus nekrosa ditemukan pada organ hati (Gambar 3c).

Lesio hati pada kasus akut dan kronis akan berbeda. Pada kasus akut ditemui adanya lesio granuloma yang berbentuk seperti donut dan terdiri atas cincin fibrin yang mengelilingi vakuola lipid (Aguilar-Olivos et al., 2013). Pada kasus kronis, temuan patologis bersifat nonspesifik antara lain infiltrasi limfosit dan adanya fokus nekrosa (Fournier et al., 1998). Pada kasus yang ditemui, infeksi berjalan kronis. Perubahan histopatologi yang bisa ditemui berupa nekrosis sel-sel hepatosit yang bersifat fokal, dan infiltrasi sel-sel radang yang terdiri atas makrofag, limfosit, dan neutrofil dengan hasil imunoreaktif terhadap C.burnetii (Gambar 4C).

Pada sampel yang diperiksa sebanyak $90 \%$ agen $Q$ fever ditemukan pada limpa, 100\% pada paru-paru, dan $100 \%$ di hati (Tabel 3). Angka ini cukup baik dengan persentase keberhasilan deteksi mencapai 96,67\% dibandingkan dengan deteksi menggunakan antibodi komersil. Limpa sebagai salah satu organ pertahanan merupakan organ yang bersifat imunoreaktif terhadap hasil imuno-histokimia 
histokimia dibandingkan paru-paru dan hati. Perbedaan distribusi C. burnetii pada berbagai organ dapat disebabkan oleh rute transmisi dari patogen tersebut. Rute utama penularan C. burnetii ialah melalui aerosol. Beberapa rute infeksi lainnya antara lain rute oral, perkutan, kontak langsung, ataupun transmisi seksual (Angelakis dan Raoult 2010). Menurut Stein et al. (2005), infeksi secara aerosol selain menyebabkan lesio pada paru-paru juga dapat menyebabkan lesio pada organ hati dan limpa. Menurut Woldehiwet (2004), setelah bermultiplikasi pada limfonodus regional, 5-7 hari berikutnya terjadi bakterimia dan lokalisasi pada kelenjar mammae dan plasenta hewan bunting. Jalur hematogen mengakibatkan C. burnetii dapat ditemukan pada hati, ginjal, limpa, sumsum tulang, saluran reproduksi, dan organ lainnya.

Kesimpulan yang dapat diperoleh dari penelitian ini antara lain bahwa antibodi anti-C.burnetii yang dihasilkan mampu mendeteksi antigen $C$. burnetii dengan metode imunohistokimia bahkan pada hewan yang asimptomatik Q Fever. Organ limpa yang menunjukkan hasil imunoreaktif cukup baik dapat dijadikan acuan untuk proses sampling. Selain itu, proses produksi antibodi dapat diadopsi untuk produksi antibodi penyakit-penyakit lain pada hewan.

\section{UCAPAN TERIMA KASIH}

Ucapan terima kasih disampaikan untuk KEMENRISTEK-DIKTI, Rumah Sakit Hewan Pendidikan FKH IPB, Laboratorium Patologi FKH IPB, Pusat Penelitian Bioteknologi LIPI, Bapak Sangkot dan pihak yang membantu penelitian.

"Penulis menyatakan tidak ada konflik kepentingan dengan pihak-pihak terkait dalam penelitian ini".

\section{DAFTAR PUSTAKA}

Aguilar-Olivos N, Manzano-Robleda MC, GutierrezGrobe Y, Chable-Montero F, Albores-Saavedra J, Lopez-Mendez E. 2013. Granulomatous hepatitis caused by q fever: a differential diagnosisof fever of unknown origin. Annals of Hepatology. 12(1): 138-141.

Angelakis E, Raoult D. 2010.Q fever. Veterinary Microbiology. 140:297-309.
Angelakis E, Raoult D. 2011.Emergence of Q fever.Iranian Journal of Public Health. 40 (3): 1-18. Arricau-Bouvery N, Rodolakis A. 2005. Is Q fever an emerging or re-emerging zoonosis?.Veterinary Research. 36: 327-349.

Ausubel FM, Brent R, Kingston RE, Moore DD, Seidman JG, Smith JA, Struhl K. 2003.Current potocols in molecular biology.John Willey \& Sons.New York. P10.1A-10.24.

Bildfell RJ, Thomson GW, Halness DM, McEwen BJ, Smart N. 2000. Coxiella burnetii infection is associated with placentitis in cases of bovine abortion. Journal of VeterinaryDiagnostic Investigation. 12(5):419-425.

Brom R, Vellema P. 2009. Q fever outbreaks in small ruminants and people in the Netherlands.Small Ruminants Research. 86:74-79.

[CDC] Central Diseases Control and Prevention. 2008. CDC bioterrorism agent. www.bt.cdc.gov/ agent/agentlist-category.asp.

Cremoux R, Rousset E, Touratier A, Audusseau G, Nicolet P, Ribaud D, David V, Le Pape M. 2011. Coxiella burnetii vaginal shedding and antibody responses in dairy goat herds in a context of clinical Q fever outbreaks. FEMS Immunology and Medical Microbiology. 64:120-122.

Day CE. 2014. Histopathology methods and protocols. Humana Press. Los Angeles.P31-43.

Duong-Ly KC, Gabelli SB. 2014. Salting out of protein using ammonium sulfate precipitation. Methods in enzymology. 541:85-94.

Fry MM, McGavin MD. 2006. Bone marrow, blood cells, and lymphatic system. In Pathologic Basis of Veterinary Disease.4th ed. Academic Press.St Louis.P743-831.

Fournier P, Marrie TJ, Raoult D. 1998. Diagnosis of Q Fever. Journal of Clinical Microbiology. 36: 182334.

Hansen MS, Rodolakis A, Cochonneau D, Jens F. Agger JF, Christoffersen $A B$, Jensen $T K$, Agerholm JS. 2011. Coxiella burnetii associated placental lesions and infection level in parturient cows. Veterinary Journal.190:135-139.

Herbert GA, Tzianabos T, Gamble WC, Chappell WA. 1980. Development and determination of hightitered, group specific fluorescent-antibody reagent for direct identification of Rickettsiae in clinical specimens. Journal of Clinical Microbiology. 11(5):503-507.

Hjorth R. 1997. Expanded-bed adsorption in industrial bioprocessing:recent developments. Trendsof Biotechnology. 15(6):230-235. 
Jones RM, Hertwig S, Pitman J, Vipond R, Aspan A, Bolske G, Mccaughey C, McKenna JP, Van Rotterdam JP, de Bruin A, Ruuls R, Bujjs R, Roest $\mathrm{H}$, Sawyer J. 2011. Interlaboratory comparison of real time polymerase chain reaction methods to detect Coxiella burnetii, the causative agent of Q fever.Journal of Veterinary Diagnostic Investigation.23:108-111.

[KEMENTAN] Kementerian Pertanian. 2013. Keputusan Menteri Pertanian Republik Indonesia Nomor 4026/Kpts./OT.140/4/2013 tentang Penetapan Jenis Penyakit Hewan Menular Strategis. KEMENTAN.Jakarta.

Kowalczweska M, Sekeyova Z, Raoult D. 2011. Proteomics paves the way for $\mathrm{Q}$ Fever diagnostic. Genome Medicine.3:50.

Kuper, D.F., E.de Heer, H.V. Loveren, J.G. Vos. 2002. Immune system. In handbook of toxicologic Coxiella burnetii antibody specific for $\mathrm{Q}$ fever pathology. (WM Haschek, CG Rousseaux and MA Diagnosis Immunohistochemically in Ruminant. Wallig, eds.). Academic Press.San Diego. 2: 585646.

Leenaars M, Hendriksen CFM. 2005. Critical steps in the production of polyclonal and monoclonal antibodies: evaluation and recommendation. ILAR Journal. 46(3):269-279.

Leroy Q, Armougom F, Barbry P, Raoult D. 2011. Genomotyping of Coxiella burnetii using microarrays reveals a conserved genomotype for hard tick isolates. Journal Plos One. 6(10):e25781.

Mahatmi H, Setiyono A, Soejoedono RD, Pasaribu FH.2007. Deteksi Coxiella burnetii penyebab Q fever pada sapi, domba dan kambing di Bogor dan Bali.Jurnal Veteriner. 8(4):180-187.

Miller JD, Curns AT, Thompson HA. 2004. A growth study of Coxiella burnetii Nine Mile phase I and phase II in fibroblast. FEMS Immunology and Medical Microbiology. 42:291-297.

Nasution SS, Setiyono A, Handharyani E. 2014. Deteksi immunohistokimia antigen Coxiella burnetii sebagai penyebab Q fever pada sapi.Jurnal Veteriner. 9(2): 147-151.

Natih KKN, Soejoedono RD, Wibawan IWT, Pasaribu FH. 2010. Preparasi immunoglobulin g kelinci sebagai antigen penginduksi antibodi spesifik terhadap virus avian influenza $\mathrm{H}_{5} \mathrm{~N} 1$ strain legok. Jurnal Veteriner. 2(11):99-106.

Oliver C, Jamur MC. 2010. Immunocytochemical methods and protocols.3rd ed. Humana Press. New York.
Parker N, Barralet JH, Bell AM. 2006. Q fever. The lancet. 367:679-688.

Ramos-VaraJA. 2005. Technical Aspects of Immunohistochemistry. Veterinary Pathology. 42: 405-426.

Rantam FA. 2005. Metode imunologi. Airlangga University Press. Surabaya.

Reverberi R, Reverberi L. 2007. Factors affecting the antigen antibody reaction.Journal of Blood Transfusion. 5:227-240.

Rodolakis A. 2014. Zoonosis in goats: How to control them. Small Ruminants Research. 121:12-20.

Santos VLSL, Williams S, Zavala G, Zhang J, Cheng S, Santos RL, Brown CC. 2009. Detection of reticuloendotheliosis virus by immunohistochemistry and in situ hybridization in experimentally infected chicken embryo fibroblast. Brazilian Journal of Veterinary Pathology. 2(1):29-34.

Setiyono A. 2014. Celullar pathogenesis of query fever in cattle.Global Veterinaria. 13(5):668-671.

Setiyono A, Subangkit M.2014. Immunohistochemical detection of Coxiella burnetii in ruminants: a case study of Q fever in Indonesia. Global Veterinaria. 12(6):865-868.

Sharafkhaneh A, Hanania NA, Kim V. 2008. Pathogenesis of emphysema from the bench to the bedside. Proceedings of The American Thoracic Society. NETT. 5:475-477.

Stein A, Luoveau C, Lepidi H, Ricci F, Baylac P, Davoust B, Raoult D. 2005. Q fever pneumonia: virulence of Coxiella burnetii pathovars in a murine model of aerosol infection. Journal of Infectious Immunology. 73(4):2469-2477.

Striegel AM, Yau WW, Kirkland JJ, Bly DD. 2009. Modern size exclusion liquid chromatography. 2nd ed.. Jhon Willey \& Sons Inc Pub. New Jersey.p

Wielders $\mathrm{CCH}$, Boerman AW, Schimmer B, Van den Brom R, Notermans DW, Van der Hoek W, Schneeberger PM. 2015. Persistent high IgG phase I antibody levels against Coxiella burnetii among veterinarians compared to patients previously diagnosed with acute $\mathrm{Q}$ fever after three tears of follow-up. Journal Plos One. 0116937:1-11.

Woldehiwet Z. 2004. Q fever (coxiellosis): epidemiology and pathogenesis. Research of Veterinary Science. 77:93-100. 